\title{
Myelodysplastic Syndrome with Gene Mutation
}

National Cancer Institute

\section{Source}

National Cancer Institute. Myelodysplastic Syndrome with Gene Mutation. NCI

Thesaurus. Code C97310.

A myelodysplastic syndrome characterized by the presence of a point mutation in one of the following genes, TP53, EZH2, ETV6, RUNX1, and ASXL1. These gene mutations are independent predictors of poor prognosis. 